\title{
Enantioselectivity for catalytic cyclopropanation with diazomalonates
}

\author{
Michael P. Doyle* and Wenhao Hu \\ Department of Chemistry, University of Arizona, Tucson, Arizona, 85721, USA \\ E-mail: mdoyle@u.arizona.edu
}
This paper is dedicated to Professor M. A. McKervey on the occasion of his retirement from Queen's University, Belfast, Ireland

(received 30 Jan 03; accepted 06 Mar 03; published on the web 24 Mar 03)

\begin{abstract}
The use of chiral azetidinone-ligated dirhodium(II) catalysts activates dinitrogen extrusion from diazomalonates and provides access to cyclopropanation products with selectivities as high as 40-50\% ee.
\end{abstract}

Keywords: Cyclopropanation, diazomalonates, chiral catalysts, asymmetric synthesis

\section{Introduction}

There are few reports of successful intermolecular cyclopropanation reactions of diazomalonates that occur with enantiocontrol, ${ }^{1,2}$ and only a limited number have documented enantioselective intramolecular cyclopropanation reactions of allyl esters of $\beta$-ketoacetates. ${ }^{3,4}$ There are two reasons for this. One is the relative unreactivity of diazomalonates toward diazo decomposition. ${ }^{5}$ The other is the placement of two like (identical) substituents on the diazo carbon that minimizes (eliminates) carbene substituent differentiation in the cyclopropanation reaction.

We have recently developed a set of chiral azetidinone-carboxylate ligands for placement on the dirhodium(II) core. ${ }^{6}$ Because the amide OCN angle is greater in these compounds than in their five-membered ring counterparts, ${ }^{7}$ the $\mathrm{Rh}$ - $\mathrm{Rh}$ bond length is increased and with it the electronic reactivity of the carboxamidate-ligated catalyst for diazo decomposition. ${ }^{8}$ These catalysts have the structure represented by $\mathbf{1}$, and they differ in reactivity towards diazo esters from their five-membered ring pyrrolidinone (2), ${ }^{9}$ oxazolidinone (3), ${ }^{10}$ or imidazolidinone (4) analogues. ${ }^{11}$ Their reactivity does in fact approach that of prolinate catalysts such as $5{ }^{12}$ often referred to as "the McKervey catalyst," or the tert-lucinate-based catalyst $\mathbf{6} .{ }^{13}$ This communication describes their selectivities in cyclopropanation in reactions of representative vinyl compounds. 


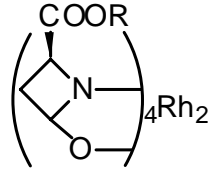

1a $\mathrm{R}=\mathrm{Me}, \mathrm{Rh}_{2}(4 S-\mathrm{MEAZ})_{4}$
1b $\mathrm{R}={ }^{i} \mathrm{Bu}, \mathrm{Rh}_{2}(4 S-I B A Z)_{4}$
1c $\mathrm{R}=\mathrm{CH}_{2} \mathrm{CMe}_{3}, \mathrm{Rh}_{2}(4 S-\mathrm{NEPAZ})_{4}$
1d $\mathrm{R}={ }^{c} \mathrm{C}_{6} \mathrm{H}_{11}, \mathrm{Rh}_{2}(4 S-\mathrm{CHAZ})_{4}$
1c $\mathrm{R}=\mathrm{PhCH}_{2}, \mathrm{Rh}_{2}(4 S-\mathrm{BNAZ})_{4}$

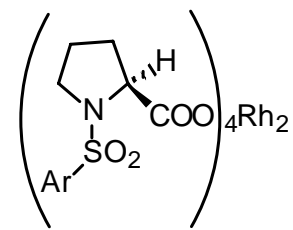

$5 \mathrm{Ar}=p$-tert-BuC ${ }_{6} \mathrm{H}_{4}$

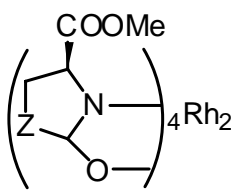

$2 \mathrm{Z}=\mathrm{CH}_{2}, \mathrm{Rh}_{2}(5 \mathrm{~S}-\mathrm{MEPY})_{4}$

$3 \mathrm{Z}=\mathrm{O}, \mathrm{Rh}_{2}(4 \mathrm{~S}-\mathrm{MEOX})_{4}$

$4 \mathrm{Z}=\mathrm{NCOCH}_{2} \mathrm{CH}_{2} \mathrm{Ph}, \mathrm{Rh}_{2}(4 \mathrm{~S}-\mathrm{MPPIM})_{4}$

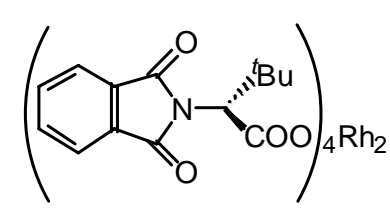

6

\section{Results and Discussion}

The common reaction with styrene was first examined under standard conditions $(1.0 \%$ mol catalyst, refluxing $\mathrm{CH}_{2} \mathrm{Cl}_{2}, 10$ equiv olefin). Dimethyl diazomalonate did not undergo decomposition during 2.5h with 2-4, but complete reaction was achieved with 1a-e, 5, and 6 under the same conditions. Product yields and measured enantioselectivities from these reactions (eq 1) are presented in Table 1. High product yields are obtained in each case, and enantioselectivities from the use of $\mathbf{1}$, especially $\mathbf{1 a}$ and $\mathbf{1} \mathbf{b}$, are the highest achieved.

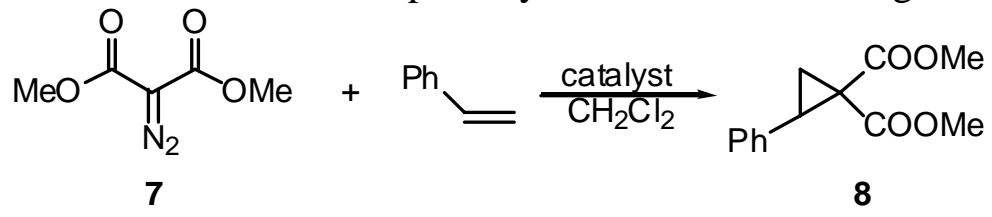

Table 1. Product yields and enantioselectivities from catalyzed reactions of dimethyl diazomalonate with styrene

\begin{tabular}{ccc}
\hline Catalyst & Yield 8, \% & ee, \% \\
\hline 1a & 97 & 44 \\
1b & 87 & 38 \\
1c & 91 & 36 \\
1d & 92 & 19 \\
1e & 88 & 25 \\
$\mathbf{5}$ & 63 & $7^{a}$ \\
$\mathbf{6}$ & 88 & 23 \\
\hline
\end{tabular}

${ }^{a}$ From ref. 2; reaction performed in pentane. 
We reasoned that placement of electron-withdrawing groups on the benzene ring of styrene might decrease the nucleophilicity of the carbon-carbon double bond towards the intermediate electrophilic metal carbene. Using p-trifluromethylstyrene (eq 2), selectivities did, in fact increase, but only modestly (Table 2). We then investigated possible steric enhancement of enantiocontrol through

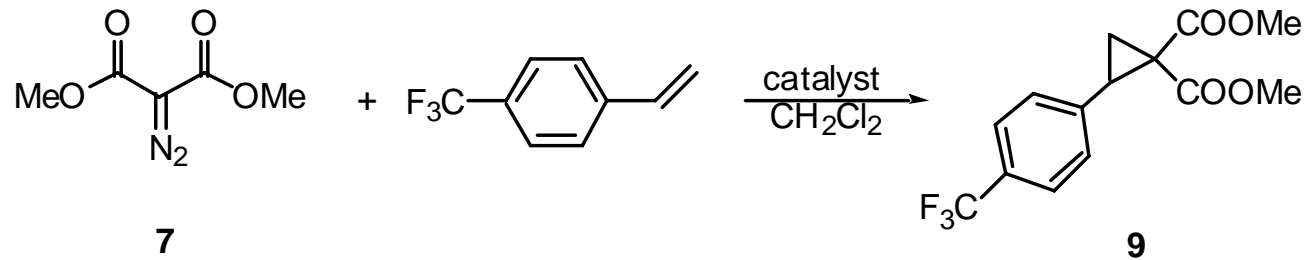

Table 2. Product yields and enantioselectivities from catalyzed reactions of dimethyl diazomalonate with $p$-trifluoromethylstyrene ${ }^{a}$

\begin{tabular}{ccc}
\hline Catalyst & Yield 9, \% & ee, \% \\
\hline 1a & 73 & 50 \\
1b & 52 & 42 \\
\hline
\end{tabular}

${ }^{a}$ Same conditions as reactions in Table 1.

the use of di-tert-butyl diazomalonate. However, these reactions were complicated by competing insertion into the ester primary carbon-hydrogen bond (eq 3) - a rare observation in reactions of this type. ${ }^{5,14}$ Results are described in Table 3. Notable is the influence of the ligand ester group in the catalyst on the extent of $\mathrm{C}-\mathrm{H}$ insertion and on enantiocontrol in cyclopropanation.<smiles>COC(=O)C(=N)C(=O)OC(C)=O</smiles>

Table 3. Product yields and enantioselectivities from catalyzed reactions of di-tert-butyl diazomalonate with styrene ${ }^{a}$

\begin{tabular}{cccc}
\hline Catalyst & Yield (11+12), \% & $\mathbf{1 1}: \mathbf{1 2}$ & ee 11, \% \\
\hline 1a & 60 & $25: 75$ & 28 \\
1c & 55 & $36: 64$ & 0 \\
1d & 65 & $59: 41$ & 0 \\
\hline
\end{tabular}

${ }^{a}$ Same conditions as reactions in Table 1. 
Two other alkenes were evaluated for enantioselective cyclopropanation with dimethyl diazomalonate. Vinyl acetate gave $\mathbf{1 3}$ in good yield and expected modest enantiocontrol (Table 4), but vinylcyclohexane underwent cyclopropanation to 14 with virtually no enantioselectivity (Table 4), and the reason for this is unknown. A complex reaction mixture was obtained in attempted cyclopropanation of $n$-butyl vinyl ether, and the mixture was not further analyzed.

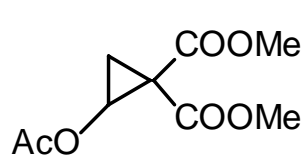

13

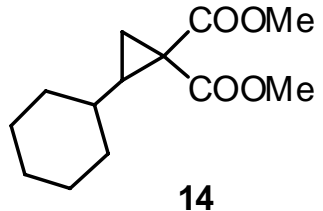

14

Table 4. Product yields and selectivities from catalyzed reactions of dimethyl diazomalonate with vinyl acetate and vinylcyclohexane ${ }^{a}$

\begin{tabular}{cccc}
\hline $\begin{array}{c}\mathrm{RCH}=\mathrm{CH}_{2} \\
\mathrm{R}=\end{array}$ & Catalyst & Yield, \% & ee, \% \\
\hline $\mathrm{AcO}$ & $\mathbf{1 a}$ & $65(\mathbf{1 3})$ & 33 \\
& $\mathbf{1 b}$ & $72(\mathbf{1 3})$ & 34 \\
${ }^{c} \mathrm{C}_{6} \mathrm{H}_{11}$ & $\mathbf{1 b}$ & $60(\mathbf{1 4})$ & 6 \\
\hline
\end{tabular}

${ }^{a}$ Same conditions as reactions in Table 1.

Efforts were also undertaken to effect intramolecular cyclopropanation with allyl diazomalonate 15 (eq 4). Here reaction conditions were identical to those typically performed for intermolecular reactions without, of course, added alkene. Analyses were the same as those reported by Koskinen and Tamm. ${ }^{4,15}$ We were gratified to find that enantiocontrol for intramolecular cyclopropanation reached new high levels, but product yields were unexpectedly low (Table 5). The reason(s) for the low yields in these reactions are not evident as yet. Further investigations are underway.

Coinciding with the initial reports of chiral semicorrin and bis-oxazoline ligands for copper, ${ }^{5}$ were the first reports of chiral (homochiral) catalysts of dirhodium(II). ${ }^{12 a, 16,17} \mathrm{M}$. A. McKervey contributed substantially and creatively to this development, and his efforts continue to influence the field. ${ }^{5,12 b, 18}$<smiles>[R]OC(=O)C(=[W])C(=O)OC/C=C/C[AlH2]</smiles>

15<smiles>[R]OC(=O)C12CCC(COC1=O)C2</smiles>

16

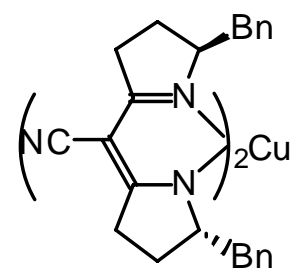

17

Table 5. Product yields and selectivities from catalyzed reactions of $\mathbf{1 5}^{a}$ 


\begin{tabular}{cccc}
\hline $\mathrm{R}=$ & Catalyst & Yield 16, \% & ee, \% \\
\hline $\mathrm{Me}$ & $\mathbf{1 a}$ & 30 & 57 \\
& $\mathbf{1 b}$ & 21 & 46 \\
& $\mathbf{1 d}$ & 14 & 42 \\
& $\mathbf{1 c}$ & 13 & 43 \\
${ }^{t} \mathrm{Bu}$ & $\mathbf{1 a}$ & 5 & 30 \\
& $\mathbf{1 7}^{b}$ & 72 & 32 \\
\hline
\end{tabular}

${ }^{a}$ Same conditions as reactions in Table $1 .{ }^{b}$ Ref. 4.

\section{Experimental Section}

\section{Cyclopropanation of styrene with dimethyl diazomalonate. ${ }^{5}$ General procedure}

A solution of dimethyl diazomalonate $13(63 \mathrm{mg}, 0.39 \mathrm{mmol})$ in dichloromethane $\left(\mathrm{CH}_{2} \mathrm{Cl}_{2}\right)$ ( $2 \mathrm{~mL}$ ) was added via syringe pump $(1.0 \mathrm{~mL} / \mathrm{hr})$ over 2 hours to a refluxing solution of $\mathrm{Rh}_{2}(4 S$ BNAZ) 4 (4.3 mg, $1.0 \mathrm{~mol} \%$ ) and styrene $(0.40 \mathrm{ml}, 3.9 \mathrm{mmol})$ in $\mathrm{CH}_{2} \mathrm{Cl}_{2}(4 \mathrm{~mL})$. After complete addition the reaction mixture was stirred at reflux for a further 30 minutes to ensure complete reaction. The mixture was then cooled to room temperature, then passed through a short silica plug, which was subsequently washed with $\mathrm{CH}_{2} \mathrm{Cl}_{2}(40 \mathrm{~mL})$. The solvent was removed at reduced pressure, to furnish the desired cyclopropane 8 (80 $\mathrm{mg}, 0.34 \mathrm{mmol}, 88 \%)$ as a colorless oil, $25 \%$ ee (determined by GC on a $30-\mathrm{m}$ Chiraldex $\beta$-DM column $100^{\circ} \mathrm{C}$ for $5 \mathrm{~min}$, then $1^{\circ} \mathrm{C} / \mathrm{min}$ to $\left.160^{\circ} \mathrm{C} \cdot \mathrm{t}_{\mathrm{R} \text { minor }}=63.4 \mathrm{~min}, \mathrm{t}_{\mathrm{R} \text { major }}=64.7 \mathrm{~min}\right) .{ }^{1} \mathrm{H} \mathrm{NMR}\left(300 \mathrm{MHz}, \mathrm{CDCl}_{3}\right) \delta 7.38-$ 7.15 (comp, 5H), 3.78 (s, 3H), 3.23 (dd, $J=9.3,7.8 \mathrm{~Hz}, 1 \mathrm{H}$ ), 2.20 (dd, $J=7.8,5.4 \mathrm{~Hz}, 1 \mathrm{H}$ ), 1.74 (dd, $J=9.3,5.4 \mathrm{~Hz}, 1 \mathrm{H}) ;{ }^{13} \mathrm{C} \mathrm{NMR}\left(75 \mathrm{MHz}, \mathrm{CDCl}_{3}\right) \delta 170.1,166.9,134.5,128.3,128.0,127.2$, 52.6, 52.0, 37.1, 32.4, 18.9 .

\section{Cyclopropanation of $p$-trifluoromethylstyrene with dimethyl diazomalonate. ${ }^{5}$ General procedure}

A solution of dimethyl diazomalonate $9(32 \mathrm{mg}, 0.20 \mathrm{mmol})$ in dichloromethane $\left(\mathrm{CH}_{2} \mathrm{Cl}_{2}\right)$ (2 mL) was added via syringe pump $(0.5 \mathrm{~mL} / \mathrm{hr})$ over 4 hours to a refluxing solution of $\mathrm{Rh}_{2}(4 S$ MEAZ) 4 (1.4 mg, $1.0 \mathrm{~mol} \%$ ) and p-trifluoromethylstyrene $(0.34 \mathrm{ml}, 2.0 \mathrm{mmol})$ in $\mathrm{CH}_{2} \mathrm{Cl}_{2}(4$ $\mathrm{mL}$ ). After complete addition the reaction mixture was stirred at reflux for a further 30 minutes to ensure complete reaction. The mixture was then cooled to room temperature, then passed through a short silica plug, which was subsequently washed with $\mathrm{CH}_{2} \mathrm{Cl}_{2}(40 \mathrm{~mL})$. The crude product was purified by flash column chromatography on silica gel eluting with $40 \%$ ethyl acetate in hexanes to furnish the desired cyclopropane 9 (44 mg, $0.14 \mathrm{mmol}, 73 \%$ ) as a colorless oil, $50 \%$ ee (determined by GC on a $30-\mathrm{m}$ Chiraldex $\beta$-DM column $100^{\circ} \mathrm{C}$ for $5 \mathrm{~min}$, then $0.5^{\circ} \mathrm{C} / \mathrm{min}$ to $\left.170^{\circ} \mathrm{C} . \mathrm{t}_{\mathrm{R} \text { minor }}=88.9 \mathrm{~min}, \mathrm{t}_{\mathrm{R} \text { major }}=91.2 \mathrm{~min}\right) .{ }^{1} \mathrm{H} \mathrm{NMR}\left(300 \mathrm{MHz}, \mathrm{CDCl}_{3}\right) \delta 7.53$ (d, $J=8.4 \mathrm{~Hz}, 2 \mathrm{H}$ ), 7.30 (d, $J=8.4 \mathrm{~Hz}, 2 \mathrm{H}$ ), 7.30 (d, $J=8.4 \mathrm{~Hz}, 2 \mathrm{H}$ ), 3.80 (s, 3H), 3.38 (s, 3H), 3.25 (dd, $J=9.0,7.8 \mathrm{~Hz}, 1 \mathrm{H}$ ), 2.20 (dd, $J=7.8,5.1 \mathrm{~Hz}, 1 \mathrm{H}), 1.78$ (dd, $J=9.0,5.1 \mathrm{~Hz}, 1 \mathrm{H}$ ); ${ }^{13} \mathrm{C}$ 
NMR $\left(125 \mathrm{MHz}, \mathrm{CDCl}_{3}\right) \delta$ 169.8, 166.7, 138.8, 128.8, 128.0, 125.1, 52.9, 52.4, 37.3, 31.8, 29.7, 19.1.

\section{Cyclopropanation of styrene with di-tert-butyl diazomalonate. General procedure}

A solution of di-tert-butyl diazomalonate 10 (97 mg, $0.4 \mathrm{mmol})$ in dichloromethane $\left(\mathrm{CH}_{2} \mathrm{Cl}_{2}\right)$ ( $2 \mathrm{~mL}$ ) was added via syringe pump $(1.0 \mathrm{~mL} / \mathrm{hr})$ over 2 hours to a refluxing solution of $\mathrm{Rh}_{2}(4 S$ $\mathrm{CHAZ}_{4}$ (3.9 mg, $1.0 \mathrm{~mol} \%$ ) and styrene (0.40 ml, $\left.3.9 \mathrm{mmol}\right)$ in $\mathrm{CH}_{2} \mathrm{Cl}_{2}$ (4 mL). After complete addition the reaction mixture was stirred at reflux for a further 30 minutes to ensure complete reaction. The mixture was then cooled to room temperature, then passed through a short silica plug, which was subsequently washed with $\mathrm{CH}_{2} \mathrm{Cl}_{2}(40 \mathrm{~mL})$. The solvent was removed under reduced pressure, to furnish a 59:41 mixture (76 mg, $0.26 \mathrm{mmol}, 65 \%$ ) of cyclopropane 11 (ee $0 \%$, determined by GC on a 30-m Chiraldex $\beta$-DM column $140^{\circ} \mathrm{C}$ isotherm, $\mathrm{t}_{\mathrm{R} \text { major }}=52.9 \mathrm{~min}$, $\left.\mathrm{t}_{\mathrm{R} \text { minor }}=53.7 \mathrm{~min}\right)$, and insertion product 12. Data for 11: ${ }^{1} \mathrm{H} \mathrm{NMR}\left(500 \mathrm{MHz}, \mathrm{CDCl}_{3}\right) \delta 7.28-$ 7.17 (comp, 5H), 3.09 (dd, $J=9.1,7.8 \mathrm{~Hz}, 1 \mathrm{H}$ ), 2.03 (dd, $J=7.8,5.1 \mathrm{~Hz}, 1 \mathrm{H}$ ), 1.52 (dd, $J=9.1$, $5.1 \mathrm{~Hz}, 1 \mathrm{H}), 1.50$ (s, 9H), 1.09 (s, 9H); ${ }^{13} \mathrm{C} \mathrm{NMR}\left(125 \mathrm{MHz}, \mathrm{CDCl}_{3}\right) \delta 169.3,65.9,135.0,128.8$, 127.9, 81.7, 80.8, 39.3, 30.9, 28.0, 27.4, 17.6. Data for 12: ${ }^{1} \mathrm{H}$ NMR (300 MHz, $\left.\mathrm{CDCl}_{3}\right) \delta 3.65(\mathrm{t}$, $J=9.9 \mathrm{~Hz}, 1 \mathrm{H}), 2.46$ (dd, $J=12.9,9.9 \mathrm{~Hz}, 1 \mathrm{H}), 2.29$ (dd, $J=12.9,9.9 \mathrm{~Hz}, 1 \mathrm{H}), 1.51$ (s, 3H), 1.50 (s, 9H), 1.41 (s, 3H); ${ }^{13} \mathrm{C}$ NMR (75 MHz, $\left.\mathrm{CDCl}_{3}\right) \delta 171.6,167.4$, 83.4, 82.7, 48.6, 38.3, 28.3, 27.8, 27.7.

\section{Cyclopropanation of vinyl acetate with dimethyl diazomalonate. General procedure}

A solution of dimethyl diazomalonate $(63 \mathrm{mg}, 0.39 \mathrm{mmol})$ in dichloromethane $\left(\mathrm{CH}_{2} \mathrm{Cl}_{2}\right)(2 \mathrm{~mL})$ was added via syringe pump $(1.0 \mathrm{~mL} / \mathrm{hr})$ over 2 hours to a refluxing solution of $\mathrm{Rh}_{2}(4 S-\mathrm{MEAZ})_{4}$ (2.8 mg, $1.0 \mathrm{~mol} \%$ ) and vinyl acetate $\left(0.34 \mathrm{ml}, 3.9 \mathrm{mmol}\right.$ ) in $\mathrm{CH}_{2} \mathrm{Cl}_{2}$ (4 mL). After complete addition the reaction mixture was stirred at reflux for a further 30 minutes to ensure complete reaction. The mixture was then cooled to room temperature, then passed through a short silica plug, which was subsequently washed with $\mathrm{CH}_{2} \mathrm{Cl}_{2}(40 \mathrm{~mL})$. The crude product was purified by flash column chromatography on silica gel eluting with $10 \%$ ethyl acetate in hexanes to furnish the desired cyclopropane 13 (56 mg, $0.26 \mathrm{mmol}, 65 \%$ ) as a colorless oil, 33\% ee (determined by GC on a 30-m Chiraldex $\beta$-DM column $100^{\circ} \mathrm{C}$ for $5 \mathrm{~min}$, then $1^{\circ} \mathrm{C} / \mathrm{min}$ to $160^{\circ} \mathrm{C}, \mathrm{t}_{\mathrm{R} \text { minor }}=33.8$ min, $\left.\mathrm{t}_{\mathrm{R} \text { major }}=34.2 \mathrm{~min}\right) .{ }^{1} \mathrm{H}$ NMR $\left(500 \mathrm{MHz}, \mathrm{CDCl}_{3}\right) \delta 4.77(\mathrm{dd}, J=7.0,5.2 \mathrm{~Hz}, 1 \mathrm{H}), 3.78(\mathrm{~s}$, 3H), 3.75(s, 3H), 2.04 (s, 3H), 1.95 (dd, J = 7.0, $5.2 \mathrm{~Hz}, 1 \mathrm{H}), 1.72$ (dd, J = $7.0 \mathrm{~Hz}, 1 \mathrm{H}$ ); ${ }^{13} \mathrm{C}$ NMR (125 MHz, $\left.\mathrm{CDCl}_{3}\right) \delta 170.2,168.4,165.8,56.8,52.8,33.9,20.4,19.3 ; \mathrm{HRMS}_{(\mathrm{FAB}}{ }^{+}$) Calcd for $\mathrm{C}_{9} \mathrm{H}_{16} \mathrm{O}_{6}: 217.0712$. Found: 217.0714.

\section{Cyclopropanation of vinylcyclohexane with dimethyl diazomalonate. General procedure}

A solution of dimethyl diazomalonate $(63 \mathrm{mg}, 0.39 \mathrm{mmol})$ in dichloromethane $\left(\mathrm{CH}_{2} \mathrm{Cl}_{2}\right)(2 \mathrm{~mL})$ was added via syringe pump $(1.0 \mathrm{~mL} / \mathrm{hr})$ over 2 hours to a refluxing solution of $\mathrm{Rh}_{2}(4 S \text {-IBAZ })_{4}$ (3.5 mg, $1.0 \mathrm{~mol} \%$ ) and vinylcyclohexane $(0.54 \mathrm{ml}, 3.9 \mathrm{mmol})$ in $\mathrm{CH}_{2} \mathrm{Cl}_{2}(4 \mathrm{~mL})$. After complete addition the reaction mixture was stirred at reflux for a further 30 minutes to ensure 
complete reaction. The mixture was then cooled to room temperature, then passed through a short silica plug, which was subsequently washed with $\mathrm{CH}_{2} \mathrm{Cl}_{2}(40 \mathrm{~mL})$. The solvent was removed at reduced pressure, to furnish the desired cyclopropane 14 (56 mg, $0.23 \mathrm{mmol}, 60 \%$ ) as a colorless oil, $6 \%$ ee (determined by GC on a 30-m Chiraldex $\beta$-DM column $140^{\circ} \mathrm{C}$ isotherm, $\left.\mathrm{t}_{\mathrm{R} \text { major }}=13.0 \mathrm{~min}, \mathrm{t}_{\mathrm{R} \text { minor }}=13.5 \mathrm{~min}\right) .{ }^{1} \mathrm{H} \mathrm{NMR}\left(300 \mathrm{MHz}, \mathrm{CDCl}_{3}\right) \delta 3.75(\mathrm{~s}, 3 \mathrm{H}), 3.71(\mathrm{~s}, 3 \mathrm{H})$, 1.89 - 1.60 (comp, 6H), 1.41 (dd, $J=7.9,4.5 \mathrm{~Hz}, 1 \mathrm{H}$ ), 1.34 (dd, $J=7.9,4.5 \mathrm{~Hz}, 1 \mathrm{H}$ ), $1.25-1.08$ (comp, 5H), 0.79 (m, 1H); $\left.{ }^{13} \mathrm{C} \mathrm{NMR} \mathrm{(75} \mathrm{MHz,} \mathrm{CDCl}_{3}\right) \delta 170.8,168.8,52.4,52.2$, 37.6, 35.0, 33.8, 32.7, 32.3, 26.1, 25.9, 25.7, 20.1; HRMS (FAB ${ }^{+}$) Calcd for $\mathrm{C}_{13} \mathrm{H}_{21} \mathrm{O}_{4}$ : 241.1440. Found: 241.1448 .

\section{Acknowledgements}

Support for this research from the National Science Foundation and the National Institutes of Health (GM-46503) is gratefully acknowledged. Thanks especially to M. A. (Tony) McKervey for his inspiration, insight, and intensity in the pursuit of excellence in the chemistry of diazo compounds and in asymmetric catalysis.

\section{References and Notes}

1. Doyle, M. P.; Davies, S. B.; Hu, W. Org. Lett. 2000, 2, 1145.

2. $\quad$ Davies, H. M. L.; Bruzinski, P.; Fall, M. J. Tetrahedron Lett. 1996, 37, 4133.

3. Pique, C.; Fahndrich, B.; Pfaltz, A. Synlett 1995, 491.

4. Koskinen, A. M. P.; Hassila, H. J. Org. Chem. 1993, 58, 4479.

5. Doyle, M. P.; McKervey, M. A.; Ye, T. Modern Catalytic Methods for Organic Synthesis with Diazo Compounds: From Cyclopropanes to Ylides; Wiley: New York, 1998.

6. $\quad$ Doyle, M. P.; Zhou, Q.-L.; Simonsen, S. H.; Lynch, V. Synlett 1996, 697.

7. Doyle, M. P.; Ren, T. Prog. Inorg. Chem. 2001, 49, 113.

8. Doyle, M. P.; Hu, W. Adv. Synth. \& Cat. 2001, 343, 299.

9. Doyle, M. P.; Winchester, W. R.; Hoorn, J. A. A; Lynch, V.; Simonsen, S. H.; Ghosh, R. J. Am. Chem. Soc. 1993, 115, 9968.

10. Doyle , M. P.; Dyatkin, A. B.; Protopova, M. N.; Yang, C. I.; Miertschin, C. S.; Winchester, W. R.; Simonsen, S. H.; Lynch, V.; Ghosh, R. Rec. Trav. Chim. Pays-Bas 1995, 114, 163.

11. Doyle, M. P.; Zhou, Q.-L.; Raab, C. E.; Roos, G. H. P.; Simonsen, S. H.; Lynch, V. Inorg. Chem. 1996, 35, 6064.

12. (a) Kennedy, M.; McKervey, M. A.; Maguire, A. R.; Roos, G. H. P. J. Chem. Soc., Chem. Commun. 1990, 361. (b) Davies, H. M. L.; Antoulinakis, E. G. Org. Rxns. 2001, 57, 1.

13. Watanabe, N.; Ogawa, T.; Ohtake, Y.; Ikegami, S.; Hashimoto, S. Synlett 1996, 85. 
14. Doyle, M. P. In Catalytic Asymmetric Synthesis, Second Edition; Ojima, I., Ed.; Wiley: New York, 2000; Chapter 5.

15. (a) Koskinen, A. M. P.; Muñoz, L. J. Org. Chem. 1993, 58, 879. (b) Wick, L.; Tamm, C.; Boller, T. Helv. Chim. Acta 1995, 78, 403.

16. Brunner, H.; Kluschanzoff, H.; Wutz, K. Bull. Soc. Chem. Belg. 1989, 98, 63.

17. Doyle, M. P.; Brandes, B. D.; Kazala, A. P.; Pieters, R. J.; Jarstfer, M. B.; Watkins, L. M.; Eagle, C. T. Tetrahedron Lett. 1990, 31, 6613.

18. Doyle, M. P.; McKervey, M. A. J. Chem. Soc., Chem. Commun. 1997, 983. 